vaccination. Thus, one fairly careful follow-up early in this century (but not a properly controlled investigation as we now understand it) showed that vaccinated babies suffered less from other infectious diseases than did the unvaccinated; but, since sickly babies and perhaps also the offspring of the less intelligent and poorer parents were likely to be included in the unvaccinated group, a bias was immediately introduced. There is no theoretical reason why the vaccinated infant should suffer more from infectious diseases than the unvaccinated; indeed, if vaccination in infancy helps to stimulate the development of the antibody-producing cells, the child might thereby be better able to resist other infections.

\section{Urinary Incontinence}

Q.-Is there any apparatus suitable for a middle-aged man who has remained incontinent after the removal of a carcinoma of the prostate? He wears a leg urinal during the day, but at night he is unable to arrange any method of keeping the bed dry.

A.-Rubber urinals for urinary incontinence are often very unsatisfactory at night. The continuous use of them is also liable to produce irritation and soreness of the glans penis. Many patients learn to sleep on their backs and to keep the bed dry by maintaining the usual wide-mouthed bottle between their thighs. If this is not possible and the bladder has a reasonable capacity, the continuous escape of urine from the urethra can sometimes be prevented by wearing a light adjustable penile clip. This means, of course, that from time to time the patient is awakened by an urgent desire to pass water, and must then remove the clip. Should these methods fail, the only thing left to do is to place some highly absorbent material on the rubber sheet, and for this purpose pads of sphagnum moss, such as were used in the first world war when patients suffering from heavily discharging wounds had to make long journeys without any chance of their dressings being changed, should be employed.

\section{Food Allergy}

Q.-Is it possible to desensitize a patient who has had asthma since the age of four and has always been allergic to fish and eggs? By avoiding fish and eggs she was completely free from asthma while at school, but she is now having occasional attacks after eating, for example, cakes which she did not know contained eggs.

A.-Desensitization in the strict sense is not possible and the value of hyposensitization to foods is questionable. The comparatively satisfactory results of pollen hyposensitization, introduced by Noon and Freeman almost forty years ago and now universally accepted, naturally led to the hope that similar satisfactory results might be obtained in cases of food allergy. Unfortunately, but very strikingly, published results show that consistently favourable results have not been obtained and that this method of treatment has been almost completely given up at the present time. Even where apparently satisfactory results were obtained it was difficult to be certain that the results were due to the hyposensitization, for it is known that $90 \%$ to $95 \%$ of children outgrow their food allergies. Hyposensitization should not be undertaken in fish-sensitive cases, nor when the sensitivity is very marked, as it is here to eggs, which even in cakes produce asthma, owing to the danger of a severe constitutional reaction.

\section{Colostomy and Pregnancy}

Q.-I have a patient, aged 23, who has a sacral colostomy to circumvent an imperforate anus. She is about to be married. Would pregnancy be liable to upset her colostomy, and what are the chances of the anal defect being passed on to her children? Her genital organs appear to be normal.

A.-Pregnancy and labour should not raise any special problem in this case, although, as always, a tendency to constipation and some difficulty in ensuring regular bowel action is to be expected. Genetic factors probably play some part in the aetiology of imperforate anus, but it does not show such a strong familial tendency as do some other malformations.
The risk of offspring being affected is probably very small, especially if none of the other relatives and antecedents of the woman have suffered congenital malformations and if the prospective husband is of untainted stock.

\section{Repeated Injection of Tetanus 'Antitoxin}

Q.- (a) When is the injection of tetanus antitoxin after an $\overrightarrow{\vec{F}}$ injury contraindicated? (b) Would it be safe to administer it routinely on several occasions to the same individual?

A. -(a) The injection of a foreign protein such as tetanus $\frac{\overline{\bar{D}}}{\overline{\bar{D}}}$ antitoxin is contraindicated, without previous sensitivity tests. $\overrightarrow{\mathrm{D}}$ in any individual with an allergic history-e.g., a recent or past $\varrho$ sufferer from asthma, hay-fever, eczema, or urticaria-since an injection of a foreign protein may induce an acute anaphylactic $\overrightarrow{0}$ reaction with death in 10 to 30 minutés. Fortunately this. form of anaphylaxis is extremely rare in man.

(b) Tetanus antitoxin may be given repeatedly at intervals $\stackrel{\omega}{\omega}$ of one week or less without risk of reaction; this procedure $\frac{O}{3}$ was recommended and often used for severe war wounds and 3 . air-raid casualties during the recent war. The main danger $\overrightarrow{-}$ from the repeat injection lies in the interval of time between $\vec{\sigma}$ the inoculations. If it exceeds ten days the patient's tissues $\underset{\infty}{+}$ become sensitized and often react violently to the second injec- $\dot{\omega}$ tion, with substernal pain and oedema of the tissues, which in $\vec{\infty}$ the glottis may cause acute respiratory obstruction. With an increasing interval of time, and depending to some extent on $\mathrm{O}$ the size of the initial dose, the risk of this type of reaction from the second injection steadily diminishes, but any person 71 giving a history of having had antiserum within recent years $\mathbb{D}$ should first be tested for sensitivity by intradermal injection of diluted antitoxin, and, if need be, desensitized before any additional antiserum is given.

\section{NOTES AND COMMENTS}

Salicyl-sulphonic Acid Test.-Dr. JAmes KAY (St. Helens, Lancs) writes: I would like to support the observation of Dr. A. Michael Davies (December 31, 1949, p. 1540) that the salicyl-sulphonic acid test is more delicate than the heat test in detecting the presence of $\bar{\partial}$ protein in the urine. It is the delicacy and simplicity of this cold test which appeal, especially to those examining large numbers of $\mathbb{Q}$ specimens of urine. In an antenatal clinic I made it a routine to test all very weakly positive salicyl-sulphonic acid tests with the heat $\overrightarrow{\overrightarrow{0}}$ test, and not invariably the latter was negative. With experience one 3 can learn to ignore the very weakly positive test.

\section{Corrections}

Since publication of the leading article "Shortage of Rh Testing Sera" (January 14, p. 108) we have been informed by Armour and $\Sigma$ Co., Ltd., that they believe supplies of bovine albumin to have been ample since 1946, and the statement in the leading article, "The 3 . latter substance [bovine albumin] is available in England only in very small quantities," may thus have given a misleading impression. $\frac{\mathrm{O}}{3}$

Mrs. T. B. Jobson (Guildford) writes: I have just been reading the obituary notice of Dr. Justina Wilson (January 14, 음 p. 132). I feel I must point out an error. It is stated that Dr. Justina N Wilson " opened a school, 'the Swedish Institute,' in Cromwello Road." This is incorrect, as the Swedish Institute was opened by $D$ Dr. Mary Coghill-Hawkes in 1904. I was one of her many students and was also a student for a short time under Dr. Justina Wilson $\bar{N}$ when Dr. Coghill-Hawkes sold her school to Dr. Wilson in 1917. O As Dr. Mary Coghill-Hawkes was a pioneer of schools of this type, I think that she should receive the credit.

In previous notices in the Supplement of B.M.A. scholarships in aid of scientific research the last date for the receipt of applications was given as April 28, 1950. This should have read Friday, March 31, 1950 , as shown at p. 50 of the Supplement this week.

All communications with regard to editorial business should be addressed to THE EDITOR, BRITISH MEDICAL JOURNAL, B.M.A. HOUSE, TAVISTOCK SQUARE. LONDON, W.C.1. TELEPHONE: EUŚTON 2111. TELEORAMS: Aitiology, Westcent, London. ORIGINAL ARTICLES AND LETTERS forwarded foro publication are understood to be offered to the British Medical Journal alone. $\sigma$ Authors desiring REPRINTS should communicate with the Publish B.M.A. House. Tavistock Square, W.C.1, on receipt of proofs. B.M.A. House, Tavistock Square, London, W.C.1 (hours 9 a.m. to 5 p.m.) TELEHONE: EUSTON 2111. TELEGRAMS: Britmedads, Westcent, London. MEMBERS' SUBSCRIPTIONS should be sent to the SECRETARY of the Association. TELEPHONE: EUSTON 2111. Telegrams: Medisecra, Westcent. London.

B.M.A. SCOTTISH OFFICE: 7, Drumsheugh Gardens, Edinburgh. 